\title{
Alanlordia, a new genus of acervuline foraminifera from the Neogene of Indonesia
}

\author{
F. T. BANNER \& M. A. SAMUEL \\ Research School of Geological and Geophysical Sciences, Birkbeck College and University College London, \\ Gower Street, London WC1E 6BT, UK.
}

\begin{abstract}
Samples from Neogene limestones of the Indonesian islands of Nias and Tuangku, west of Sumatra, have yielded assemblages of foraminifera which include Alanlordia niasensis niasensis n.gen., n.sp., in the Late Pliocene, a new Acervulinid which grossly homeomorphs the Maastrichtian Vanderbeekia of the Middle East, while the Serravallian limestones contain the ancestral $A$. niasensis primitiva, n. subsp., and the deeper marine and morphologically simpler $A$. banyakensis n. sp., which grossly homeomorphs Wilfordia of the Eocene. J. Micropalaeontol. 14(2): 107-117, October 1995.
\end{abstract}

\section{INTRODUCTION}

The islands of Nias and the Banyak Group, Indonesia, have formed the focus for an ongoing study to establish the geological evolution of the Sumatran Forearc during the Tertiary. Nias lies to the west of the Sumatran mainland, at the outer edge of the Sunda Forearc basin; the Banyak Islands lie in the central region of the forearc (Fig. 1). During three field seasons, over 1000 rock samples have been collected from these islands and 350 of these have been analysed micropalaeontologically and stratigraphically. One sample from Nias and two samples from the Banyak Group have yielded abundant specimens of new taxa of 'larger' rotaline foraminifera. These are described in this paper.

\section{REGIONAL AND STRATIGRAPHIC SETTING}

Recently published geological work on the islands of the Sumatran Forearc (Harbury \& Kallagher 1991; Moore et al. 1980) has been concentrated on Nias. Other detailed stratigraphical work had previously been carried out between 1939 and 1941 by geologists operating on behalf of petroleum companies. Bemmelen (1949) reported on the work of two Dutch companies, but work by Union Oil geologists between 1969 and 1971 remains unpublished. Information on the Banyak Islands is limited to the report of Elber's study, carried out in 1939 and published by Bemmelen (1949). It appears that, of the three specific localities referred to in this paper, only the outcrop on Nias had previously been discovered, and even this remained unsampled for microbiostratigraphic study.

Figures 2 and 3 indicate the localities of samples Nias 1, Banyak 1 and Banyak 2. All are calcarenites. Sample Nias 1 came from an outcrop in the Gawo river of eastern Nias, and the Banyak samples came from coastal outcrops on Tuangku, the largest island of the Banyak Group. The stratigraphic positions of the samples is tied into a single chronostratigraphic column for the Banyak Islands and the Gawo region of Nias (Fig. 4).

Sample Nias 1 has been referred to the Late Pliocene as it is from an outcrop which unconformably overlies Early Pliocene sediments and which is conformably overlain by Late Pliocene and Pleistocene sediments. The sample yielded on sectioning the holotype and topotypic paratypes of the new foraminiferal taxon Alanlordia niasensis s.s. The sample also contained species of the foraminifera Amphistegina, Cellanthus, Elphidium, Operculina, Operculinella, Sorites and miliolids, with bioclasts of rhodophyte algae, bivalves, bryozoa and corals; in addition, there were many small calcarenitic lithoclasts. The sediment appears to have been shallow marine in origin, forming on the inshore part of the shelf of an island which was undergoing uplift and erosion. The many specimens of Alanlordia niasensis s.s. show little or no evidence of abrasion or other erosion, and no evidence of significant allochthoneity. The sample came from a $30 \mathrm{~cm}$ thick calcarenite bed in a $3 \mathrm{~m}$ thick exposed section of calcarenites. This limestone unit forms a marker horizon in east Nias that can be traced discontinuously along the strike of the island for $12 \mathrm{~km}$. These limestones lie conformably below a sequence of terrigenous clastic sediments which are also interpreted as being shallow marine deposits.

Banyak 2 is situated about $5 \mathrm{~m}$ stratigraphically above Banyak 1, in a $30 \mathrm{~m}$ thickness of limestones. These limestones are stratigraphically equivalent to Early and Middle Miocene limestones exposed in eastern Nias and they share similar sedimentological characteristics. Bed thicknesses of the calcarenites and calcirudites range from $30 \mathrm{~cm}$ to $1 \mathrm{~m}$, and all the limestones contain microfaunas indicating shelfal deposition. Sample Banyak 2 contains the holotype and paratypes of Alanlordia banyakensis, the other species described as new in this paper. It also contains Katacycloclypeus annulatus (Martin), Miogypsina cf indonesiensis Tan, M. spp., Lepidocyclina delicata Scheffen, $L$. cf gigantea (Martin), L. cf omphalus Tan, Nephrolepidina cf dehiscens (Scheffen), Planorbulinella larvata (Parker \& Jones), Amphistegina, Gypsina, with coral, bivalve and echinoid debris (slide P.52881 in the BM(NH) collection); it probably belongs to the Tf2 'letter-stage' and to the middle Serravallian. Sample Banyak 1 contains Amphisorus, Cellanthus, Amphistegina, Operculinella, similar metazoan bioclasts, but no microfossil evidence for firm biostratigraphy; both it and sample Banyak 2 contain $A$. niasensis primitiva n.subsp., and both samples are probably Serravallian in age (Fig. 4). 


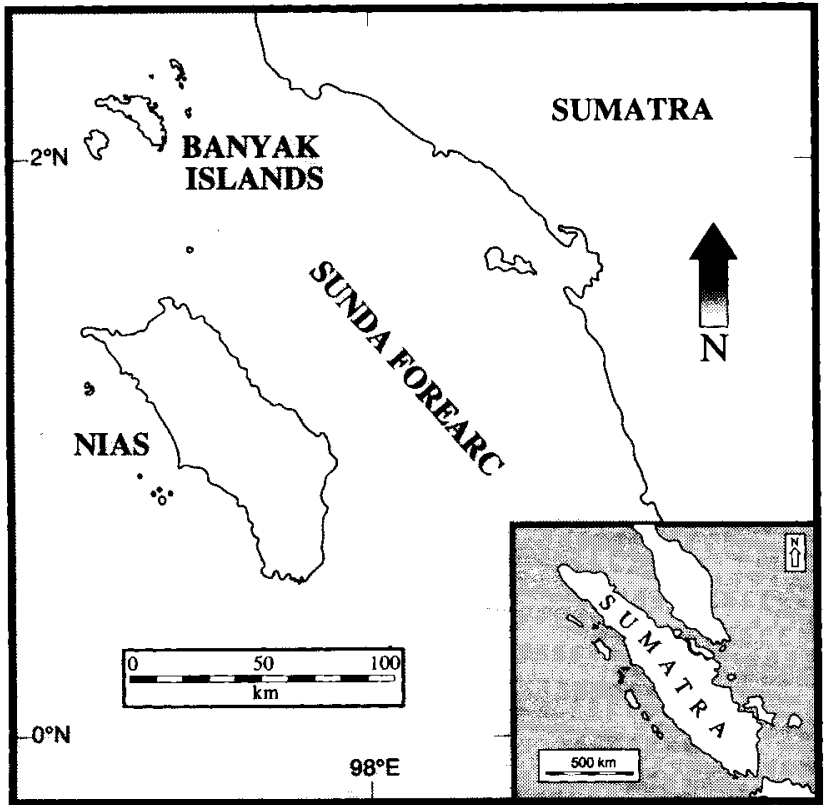

Fig. 1. Location map of the Banyak Islands and Nias.

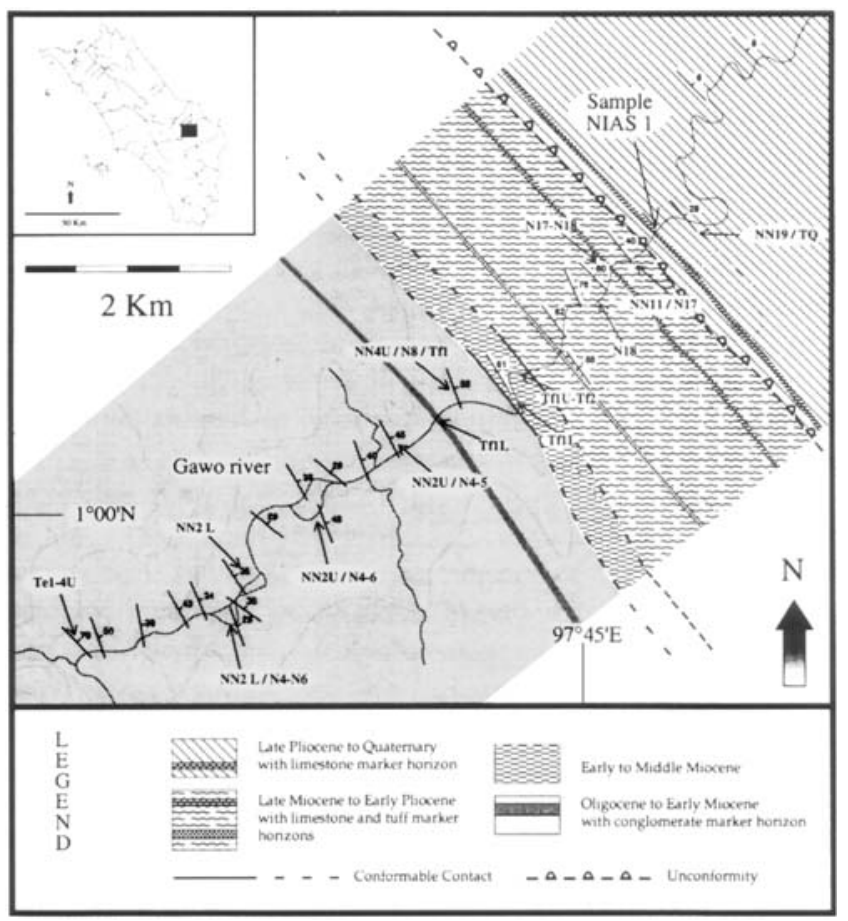

Fig. 2. Geological map of the Gawo River in eastern Nias, with a legend which also applies to Fig. 3; the outcrops are marked with indications of their biostratigraphic age, in terms of the nannofossil zones (NN), globigerinacean zones $(N)$ and/or Eastern Tethyan Tertiary 'letter-stages'. The locality of the sample Nias 1 is shown.

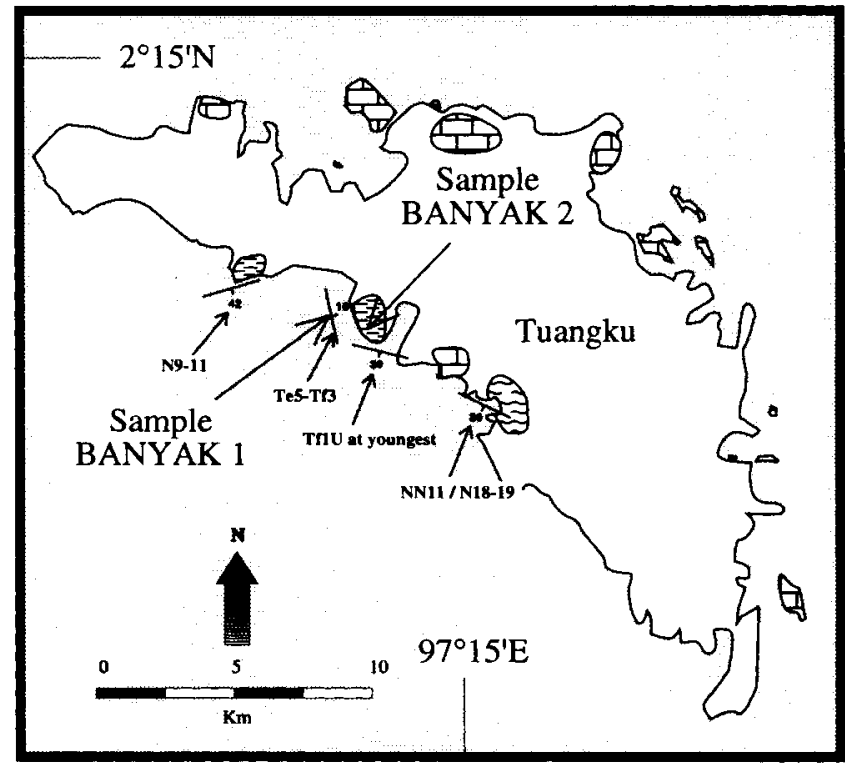

Fig. 3. Geological map of Tuangku, the largest island in the Banyak Group. The localities of samples Banyak 1 and Banyak 2 are shown. For legend, see Fig. 2.

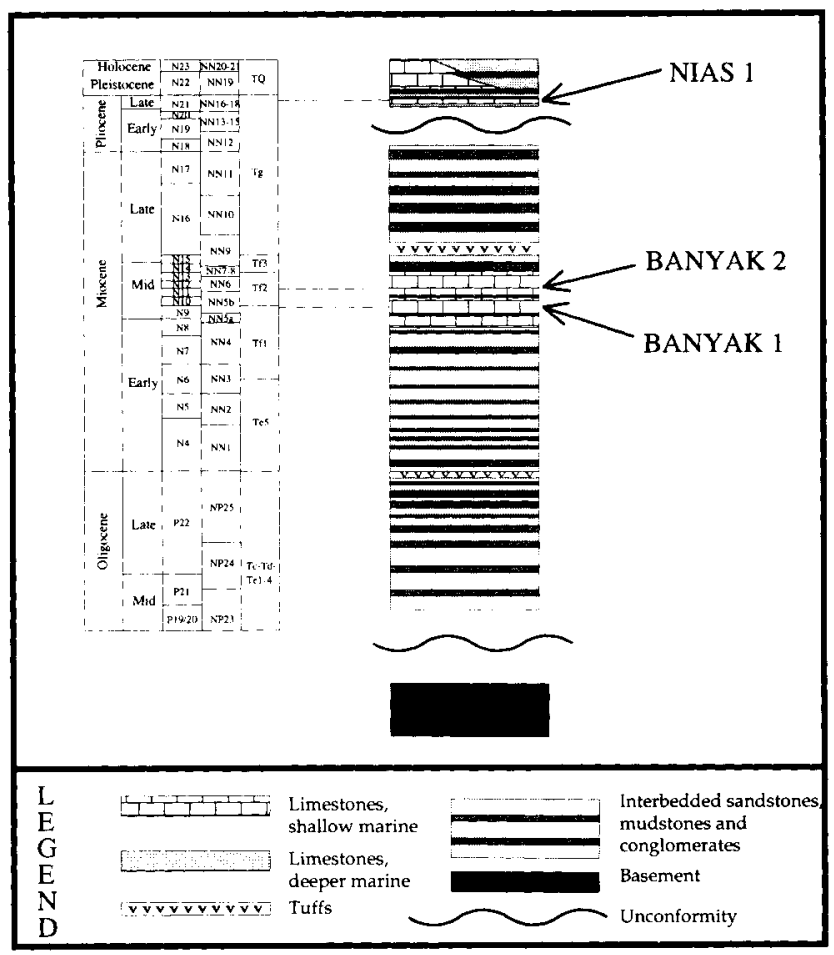

Fig. 4. Chronostratigraphic column for the Banyak Islands and the Gawo region of Nias.

\section{Explanation of Plate 1}

Fig. 1. Alanlordia niasensis niasensis n.gen., n.sp. Holotype. BM(NH) P 52875. Sample Nias 1, Late Pliocene. Near-equatorial thin section, $\times 80$. Showing initial spire around the megalospheric proloculus, with the heavy dorsal pillaring cut obliquely and an equally oblique cut of the ventral lateral chambers. Fig. 2. Detail of Fig. 1, $\times 200$. Showing the basal (interiomarginal) simple septal aperture which links successive chambers of the spire, but also the initiation (in the peripheral parts of the walls of the spiral chambers of the cribrate, pore-like areal apertures which link to the succeeding lateral chambers. The walls of the lateral chambers are so thick that these areal apertures resemble stoloniferous canals. 


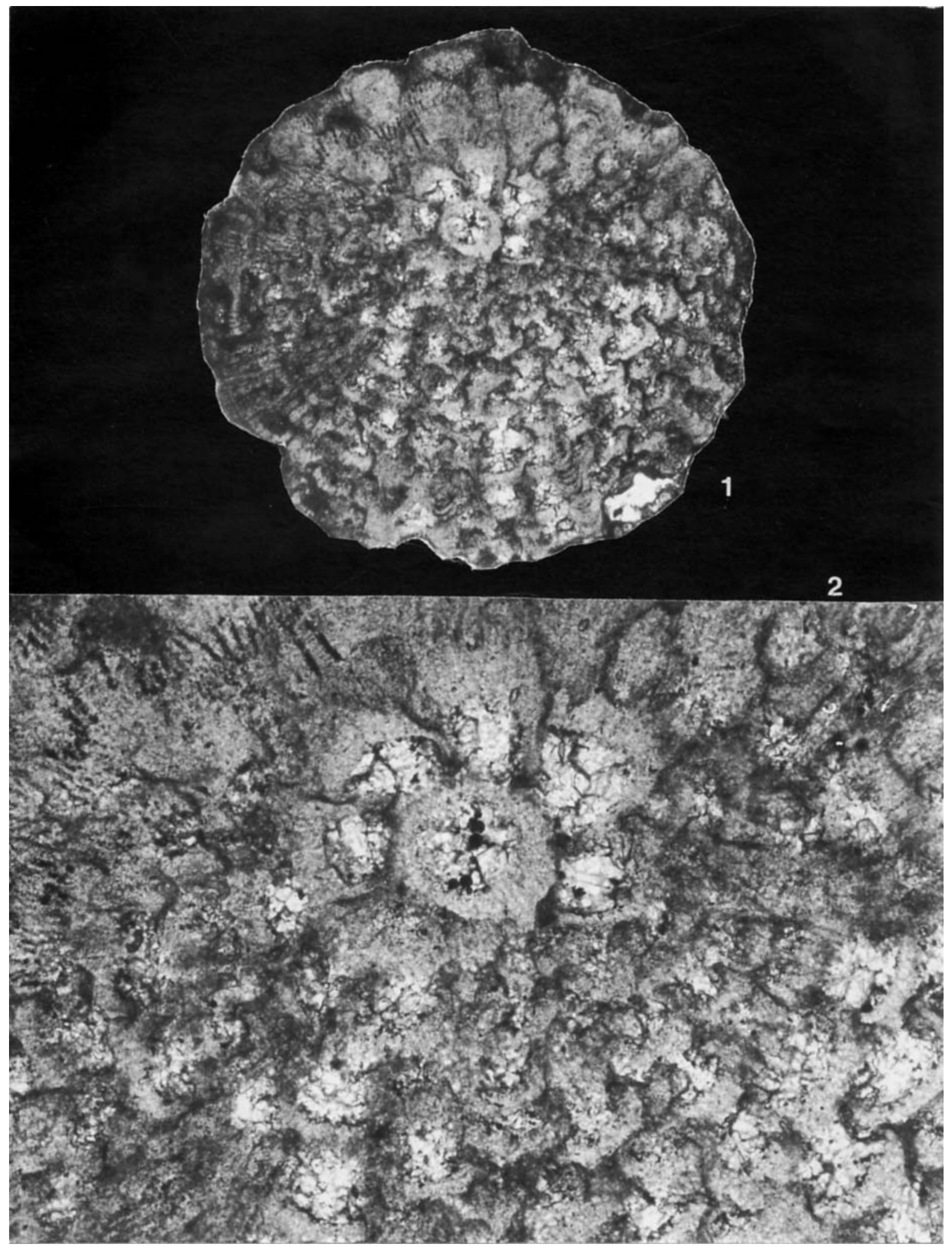

Plate 1 


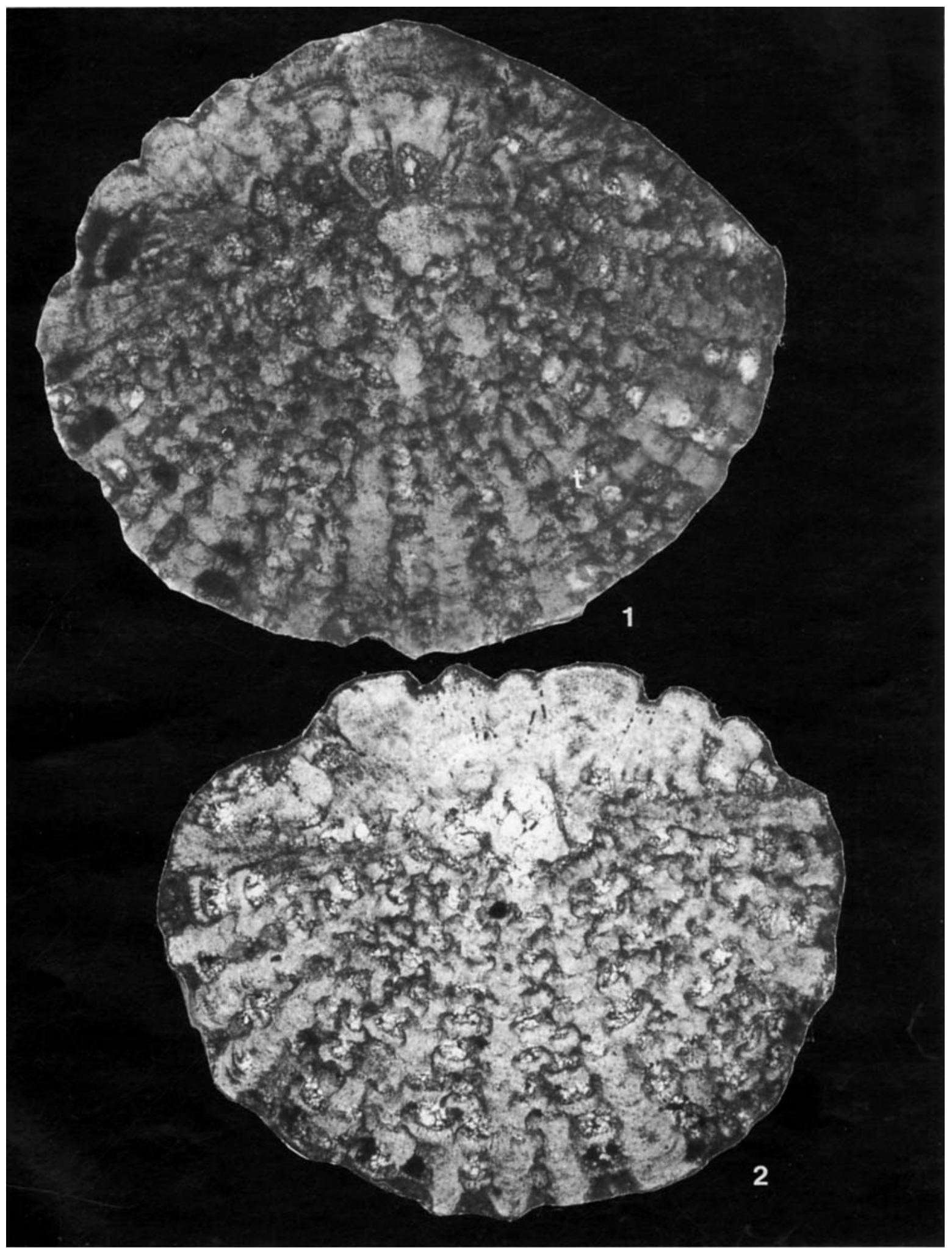

Plate 2 


\section{SYSTEMATIC DESCRIPTIONS}

The specimens described and figured in this paper are deposited in the Natural History Museum, London, in the collection of Foraminifera curated by Micropalaeontology. All are random thin-sections; each slide is separately numbered (each number prefixed by $\mathbf{P}$ ). The systematic suprageneric classification follows that given by Loeblich \& Tappan (1987).

\section{Order Foraminiferida Eichwald, 1830 \\ Suborder Rotaliina Delage \& Herouard, 1896 \\ Superfamily Acervulinacea Schultze, 1854 \\ Family Acervulinidae Schultze, 1854 \\ Genus Alanlordia nov. \\ Type species: Alanlordia niasensis nov.}

Derivation of name. This genus is named in honour of Professor Alan R. Lord, Department of Geological Sciences, University College London, for his work in running the Postgraduate Unit of Micropalaeontology in that department and for his constant help and encouragement over the past decade.

Generic diagnosis and description. Biconvex, multithalamous, calcareous (calcitic) test. Proloculus followed by a single, nearly planispiral whorl of triangular chambers (Plate 1), each successively linked by a single basal, interiomarginal, septal aperture (Plate 1), but in which multiple, cribrate, pore-like apertures develop in their distal, outermost walls. This single, initial whorl lies in a median plane which may be flat or which may be slightly concave towards the ventral side of the test. The initial whorl is succeeded both dorsally and ventrally by layers of small chambers which are added in radial rows to form successive layers of small chambers and a biconvex, lensiform test (the ventral side being more strongly convex); these chambers communicate with succeeding chambers in the next layers by cribrate, pore-like, small apertures (Plates 1 and 3). Radially developed pillars may develop in the median plane and both ventrally and dorsally; dorsally, the pillars may be very thick though separate (Plates 1, 4), but centrally, above the proloculus, they may sometimes coalesce (Plates 2, 4, 6) to fuse and develop into a solid test thickening (Plates 3, 4), parallel to what would have been the dorsal layers of lateral chambers.

Known stratigraphic range. Middle Miocene (Early Serravallian) to Late Pliocene, from land outcrops near Sumatra, Indonesia.

Remarks. Alanlordia is referred to the Acervulinidae because the initial spiral stage is followed by spreading chambers in more than one layer which appear to possess no apertures other than the pore-like cribrate openings in their upper, distal surfaces. It differs from all other known genera of this family (see Loeblich \& Tappan, 1987) by its characteristic pillaring and frequent dorsal thickening. The only Acervulinid which at all resembles it is Wilfordia (Adams, 1965), from the Eocene of Sarawak, but that genus has no true initial spire, relatively weak 'pseudopillars', no massive thickenings, and its chambers are clearly rectangular in section.

The Acervulinidae is a Cenozoic family. However, the closest homeomorph for Alanlordia (especially A. niasensis) appears to be Vanderbeekia Brönnimann \& Wirtz (1962) from the Maastrichtian of Iran. This genus was placed by Loeblich \& Tappan (1987) in the subfamily Clypeorbinae of the family Lepidorbitoididae, but was referred by Ragagi (1992) to the subfamily Neumannitinae of the family Rotaliidae; in each case the subfamilial groups are believed to be of Late Cretaceous age only. Vanderbeekia is monotypic ( $V$. trochidiformis) and is known only from oil-well cuttings (6140-6180 ft depth, well A-1, off-shore Persian Gulf) from the Gurpi Formation (Rahagi, 1992, pp. 123, 124); it has been seen there not only by its original authors but also by Rahagi (1992), but it has not yet been found at other localities. V. trochidiformis has a shape, structure and size similar to those of Alanlordia niasensis, with very similar pillaring and dorsal thickening; however, Vanderbeekia (like its close relatives Sirtina, Iranites and Neumannites) appears to have had a distinct medial layer of thick-walled chambers, unlike the very short, single initial coil of Alanlordia.

\section{Alanlordia niasensis nov.sp.}

(Pl. 1, Pl. 2, Pl. 3, Pl. 4)

Derivation of name. From the island of Nias, Indonesia, from which the primary types of the sensu stricto form of this species were obtained.

Diagnosis. A species of Alanlordia characterized by strong dorsal radial pillars, which coalesce in the central zone and which form a characteristically thick dorsal layer of calcite, eliminating most or all of the dorsal lateral chambers in the central area of the dorsal side of the test.

Description. A species of Alanlordia n.gen., as described above, in which the globular proloculus is succeeded by a single whorl of about seven chambers, each being subtriangular in the median plane but reniform in the vertical plane. The whorl is succeeded by radial rows of small chambers, each communicating with the next by small, cribrate, pore-like apertures. Dorsally to the proloculus, the pillars are thick and contiguous, especially in the middle of the dorsal volume, and may coalesce to

\section{Explanation of Plate 2}

Fig. 1. Alanlordia niasensis niasensis, paratype. BM(NH) P 52875. Sample Nias 1 , Late Pliocene. Near-vertical thin section, $\times 88$. Showing part of the initial spire (shown more completely on Plate 1), with the areal cribrate apertures developing in the peripheral parts of the chamber walls, the heavy dorsal pillaring with the pillars becoming laterally contiguous, and the weaker but still radial ventral pillaring which develops between adjacent columns of chamberlets. Fig. 2. Alanlordia niasensis niasensis, paratype. BM(NH) P 52875. Sample Nias 1 , Late Pliocene. Vertical, nearly centred thin section, $\times 82$. Showing heavy, contiguous dorsal pillars which are laterally fused together (still leaving a few cribrate apertures open as stoloniferous canals) and the separated ventral pillars; the latter form between vertical rows of chamberlets, in which successive chamberlets are linked by normal cribrate, pore-like apertures (best seen on the left of the specimen). 


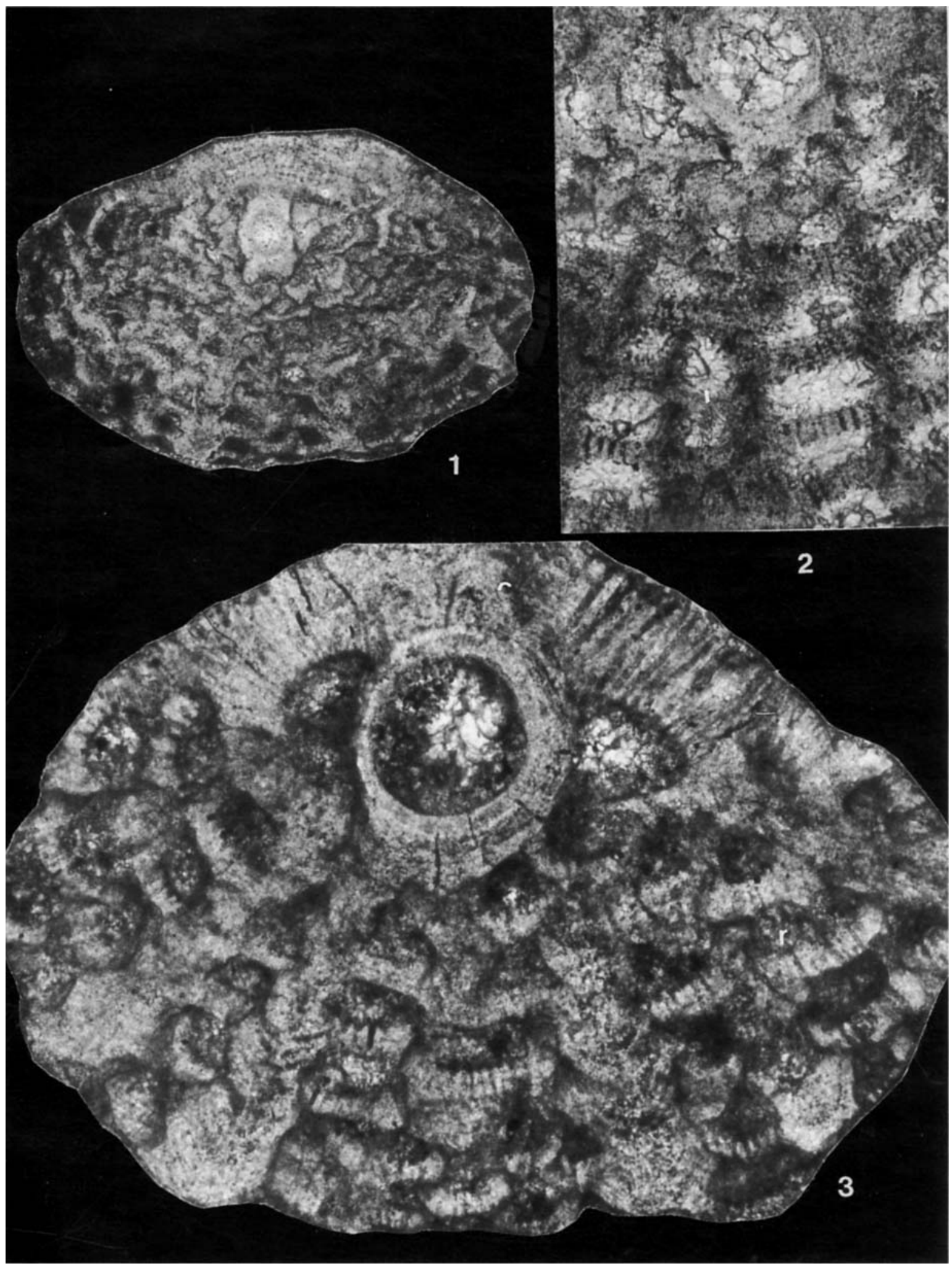

Plate 3 
form a solid, lamellar thickening. In the median plane the separated pillars are finely canaliculate. Ventrally, the pillars radiate separately, with radial rows of chambers between them, but may be strong and are not clearly (if at all) canaliculate.

Alanlordia niasensis n.sp. sensu stricto

(Pl. 1, figs 1, 2; Pl. 2, figs 1, 2; Pl. 3, figs 1-3)

Diagnosis. The subspecies of $A$. niasensis in which the walls of the ventral and dorsal chambers are thick (occupying about one-third to one-half of the total height of the chamber) so that their multiple cribrate, pore-like apertures take on the appearance of stoloniferous canals.

Holotype. That specimen figured on Plate 1, deposited in the British Museum (Natural History), catalogue no. P.52875.

Material. Several dozen specimens in random thin sections from limestone sample Nias 1.

Locality and horizon. From an outcrop on the Gawo River, eastern Nias, Indonesia, sample Nias 1 (Fig. 2), believed to be of Late Pliocene age (Fig. 4).

Stratigraphy. Known only from the Late Pliocene of Indonesia.

Alanlordia niasensis primitiva s. subsp. (P1. 4, figs. 1-3)

Diagnosis. The subspecies of $A$. niasensis in which the walls of the ventral and dorsal chambers are thin, occupying about one-quarter to one-fifth of the total height of each chamber.

Holotype. The specimen illustrated on Plate 4 as fig. 2, deposited in the British Museum (Natural History) catalogue no. P 52878.

Material. Several dozen random thin sections from limestone sample Banyak 1. Rare in sample Banyak 2.

Locality and horizon. From an outcrop on western Tuangku, Banyak Islands, Indonesia (Fig. 3), believed to be of Early to Middle Serravallian age (Late Tf1 and/or Tf2) (Fig. 4).

Stratigraphy. Known only from the Middle Miocene of Indonesia.

Alanlordia banyakensis n. $\mathrm{sp}$.

(P1. 5, figs 1, 2; P1. 6, figs 1-3)

Derivation of name. From the Banyak Islands, west of Sumatra, Indonesia.
Diagnosis. A species of Alanlordia, as described above, in which the dorsal pillaring is much reduced and often weak (the dorsal pillars usually becoming the same strength as those of the ventral part of the test), the dorsal lamellar thickening is absent and the post-prolocular chamber walls are thin (constituting about three-tenths or one-fifth of the total height of each chamber).

Holotype. The specimen illustrated on Plate 5 as fig. 1, deposited in the British Museum (Natural History) catalogue no. P 53879.

Material. More than one dozen specimens in random thin-section of sample Banyak 2.

Locality and horizon. From an outcrop on western Tuangku, Banyak Islands, Indonesia (Fig. 3), believed to be of Middle Serravallian age (probably Tf2) (Fig. 4).

Stratigraphy. Known only from the Middle Miocene of Indonesia.

Description. The globular proloculus is followed by a single whorl of seven to eight chambers, which develop multiple, cribrate, pore-like apertures on the outer peripheries. These are followed by layers of small chambers, both ventrally and dorsally, so that a bioconvex, lensiform test develops. The chambers develop in radial rows, except in the median plane, where new radial rows may be interpolated between others (Pl.6, fig. 1) or where the chambers become very long, in proportion to others, and lie alternately on either side of the spinose median plane (Pl.5, fig. 1). The cribrate multiple apertures of these chambers may be seen when the walls are cut obliquely (e.g. Pl. 6, figs 2,3). The pillars of the dorsal and ventral sides of the test are radial and solid (Pl.5, fig. 2; Pl.6, fig. 3), but the spines of the median layer are canaliculate (Pl.5, fig. 2; Pl. 6, figs 1-3) and may project beyond the surface of the rest of the test (Pl.6, figs 1, 3).

Remarks. Alanlordia banyakensis is morphologically more primitive than either of the known subspecies of $A$. niasensis; a simple evolutionary progression is easily envisaged, where the weak pillars of $A$. banyakensis become strong, with polar lamellar thickenings, in $A$. niasensis primitiva, and then the lateral chamber walls also thicken and strengthen in $A$. niasensis niasensis. However, sample Banyak 2, from which the type specimens of $A$. banyakensis were obtained, is known from its field relationships (Fig. 4) to be stratigraphically younger in the Serravallian limestones than sample Banyak 1, the type sample for $A$. niasensis primitiva. It is believed that these

\section{Explanation of Plate 3}

Alanlordia niasensis niasensis, n.sp., n.subsp., paratypes. All from sample Nias 1, Late Pliocene. Fig. 1. Paratype, BM(NH) P 52876. Vertical, centred thin section, $\times 85$. Showing dorsal pillars which have become not only laterally contiguous but laterally fused to form a strong, dorsal test thickening. Fig. 2. Paratype, BM(NH) P 52876. Vertical, centred thin section, $\times 250$. Showing the cribrate, pore-like apertures between successive ventral chamberlets but the absence of lateral canals or other apertures between adjacent chamberlets of the same annuli, even when pillars are missing. Fig. 3. Paratype, BM(NH) P 52875. Vertical, centred thin section of juvenile specimen, $\times 188$. Showing the development of stoloniferous canals through the dorsal thickening, originating from the cribrate, pore-like apertures of the thickened dorsal walls of the spiral and succeeding lateral chambers. The thick walls of the ventral lateral chambers are penetrated by normal cribrate, pore-like, areal apertures, linking successive lateral chambers. 


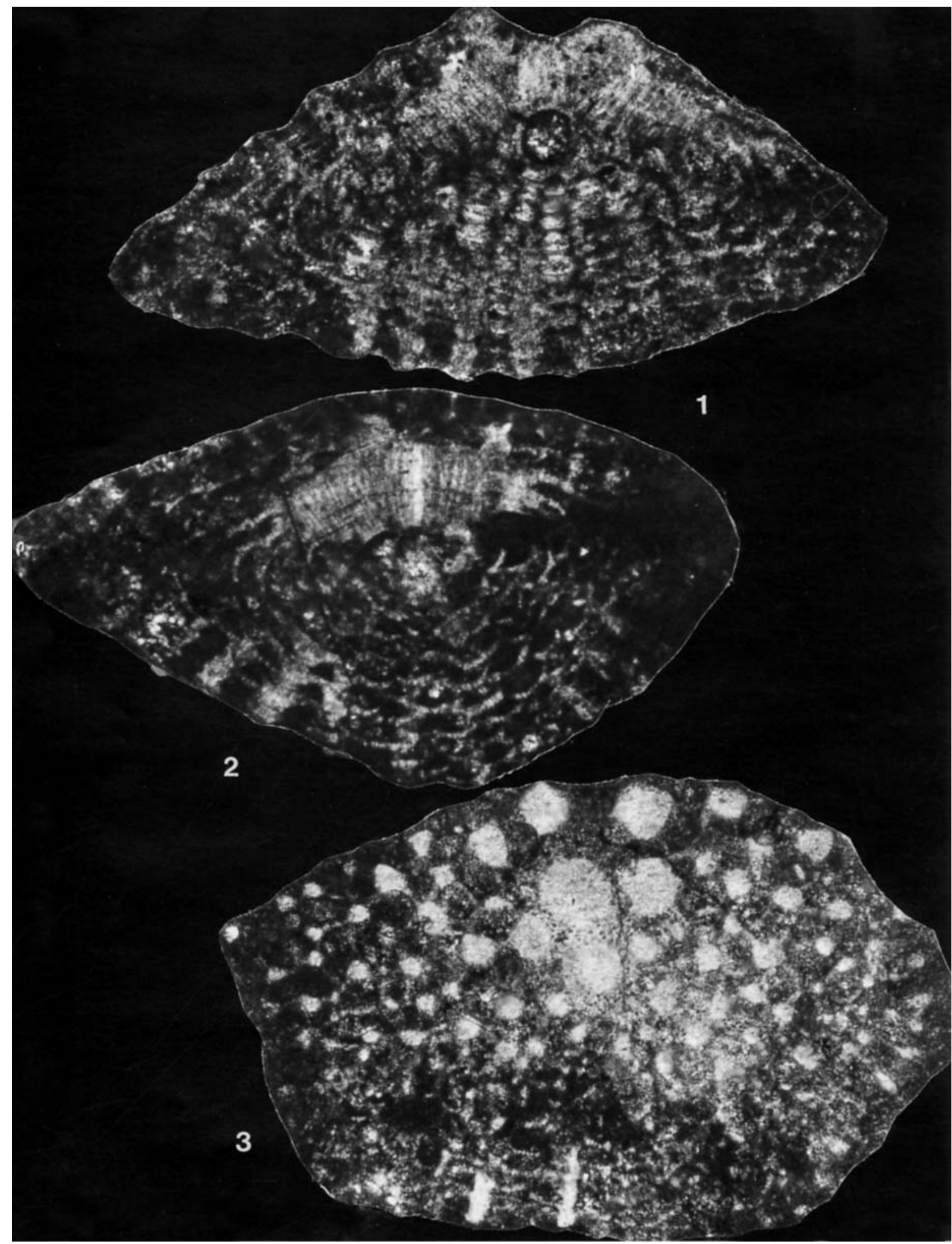

Plate 4 
two taxa coexisted (probably throughout all of the Serravallian), but were separated palaeoecologically. Sample Banyak 2 contains the rich assemblage of lepidocyclines, miogypsines, cycloclypeids, Amphistegina, etc, with echinoid, mollusc and coral debris. In contrast, sample Banyak 1 contains elphidiids, operculines, soritids, Amnphistegina, microgastropods and coral and bivalve debris, but no lepidocyclines, miogypsines, cycloclypeids or quartz grains. Nias 1 is very similar, but also has large miliolids and rhodophyte clasts. It may be suggested that A. banyakensics, as preserved in the association of sample Banyak 2, lived in an open marine, middle shelf environment which had no seawards protection from any coral reef, whereas $A$. niasensis sensu lato was rare in sample Banyak 2 and occurred abundantly (samples Banyak 1 and Nias 1) only in shallower waters (large miliolids, soritids) in environments probably protected from the open sea by coral reefs.

Alanlordia banyakensis resembles Wilfordia from the Eocene of Sarawak (Adams, 1965), but lacks the rectangular chambers, and yet possesses one initial post-prolocular whorl of chambers as well as clear dorsal pillars centrally.

\section{CONCLUSIONS}

Alanlordia banyakensis is first known from the Middle Miocene, but resembles the Palaeogene Wilfordia, from which it may have descended. Strengthening of the ventral and dorsal pillars with the thickening of chamber walls led to the development of heavily pillared forms with lamellar lateral thickenings ( $A$. niasensis niasensis) in the Pliocene, which grossly homeomorph the Maastrichtian Vanderbeekia of the Middle East. However, Alanlordia seems to be confined to carbonate-depositing, clean, middle to inner shelf, marine palaeoenvironments of the Neogene of the tropical Far East. In that area, it is potentially a biostratigraphically valuable taxon.

\section{ACKNOWLEDGEMENTS}

This study has been sponsored by the British Petroleum Co. Plc. The work has been carried out in collaboration with the Research and Development Centre for Oil and Gas Technology (LEMIGAS), Jakarta, without whose generous help the fieldwork would have proved impossible.

\section{Manuscript received December 1993 Manuscript accepted June 1994}

\section{REFERENCES}

Adams, C. G. 1965. The foraminifera and stratigraphy of the Melinau Limestone, and its importance in Tertiary correlation. Quarterly Journal of the Geological Society, London, 121: 283-338.

Bemmelen, R. W. van 1970 (1st ed. 1949) The Geology of Indonesia. 3 vols. Government Printing Office, Nijhoff. The Hague.

Brönnimann, P. \& Wirtz, H. 1962. New Maastrichtian Rotaliids from Iran and Libya. Eclogae Geologicae Helvetiae. Basel. 55: $519-529$

Harbury, N. A. \& Kallagher, H. J. 1991. The Sunda Outer-Arc Ridge, North Sumatra, Indonesia. Journal of Southeast Asian Earth Sciences, Oxford, 6: 463-476.

Loeblich, A. R. Jr. \& Tappan, H. 1987 (1988). Foraminiferal genera and their classification. Van Nostrand Reinhold Co., New York.

Moore, G. F., Billman, H. G., Hehanussa, P. E. \& Karig, D. E. 1980. Sedimentology and palaeobathymetry of Neogene trenchslope deposits, Nias Island, Indonesia. Journal of Geology, Chicago 88: $161-180$

Rahagi, A. 1992. Remarks on the genera Sirtina, Vanderbeekia, Iranites and Neumannites (Foraminifera) from Upper Cretaceous of Iran with suggestion of a new subfamily Neumannitinae. Revista Española de Micropaleontologia, Madrid. 24: 119-129.

\section{Explanation of Plate 4}

Alanlordia niasensis primitiva, n.sp., n.subsp., holotype and paratypes from sample Banyak 1, Early Serravallian. Showing the thin walls of the lateral chambers, characteristic of this subspecies: fig. 3, BM(NH) P 52877. Fig. 1. paratype, centred vertical section, with separated dorsal pillars $\times 80$ figs 1,2 , both $\mathrm{BM}(\mathrm{NH}) \mathrm{P} 52878$. Fig. 2. paratype, centred vertical section with dorsal pillars fused to create solid, lamellar dorsal thickening $\times 76$. Fig. 3. paratype, oblique section showing greatest thickness of pillars in the middle of the dorsal side of the test, the pillars thinning and separating towards the periphery of the median plane of the test. $\times 83$.

\section{Explanation of Plate 5}

Fig. 1. Alanlordia banyakensis n.sp., holotype. Vertical centred section through proloculus, BM(NH) P $52879 \times 88$. From sample Banyak 2 , Middle Serravallian. Fig. 2. Alanlordia banyakensis n.sp., paratype. From sample Banyak 1, Middle Serravallian. Slightly oblique (from vertical) section, nearly centred (through side of proloculus), BM(NH) P $52879 \times 95$.

\section{Explanation of Plate 6}

Alanlordia banyakensis n.sp., paratypes. From Sample Banyak 2, Middle Serravallian. Showing canaliculate and projecting spines of the median layer. Fig. 1. Paratype. Vertical off-centred section, $\times 83$, showing minimum observed development of ventral and dorsal spines. $\mathrm{BM}(\mathrm{NH})$ P 52879. Fig. 2. Paratype. Oblique off-centred section, BM(NH) P 52880. $\times 83$. Fig. 3. Paratype. Oblique off-centred section, $\mathrm{BM}(\mathrm{NH}) \mathrm{P}$ 52880, $\times 83$; showing maximum observed development of dorsal pillars and normal (typical) development of ventral pillars. 


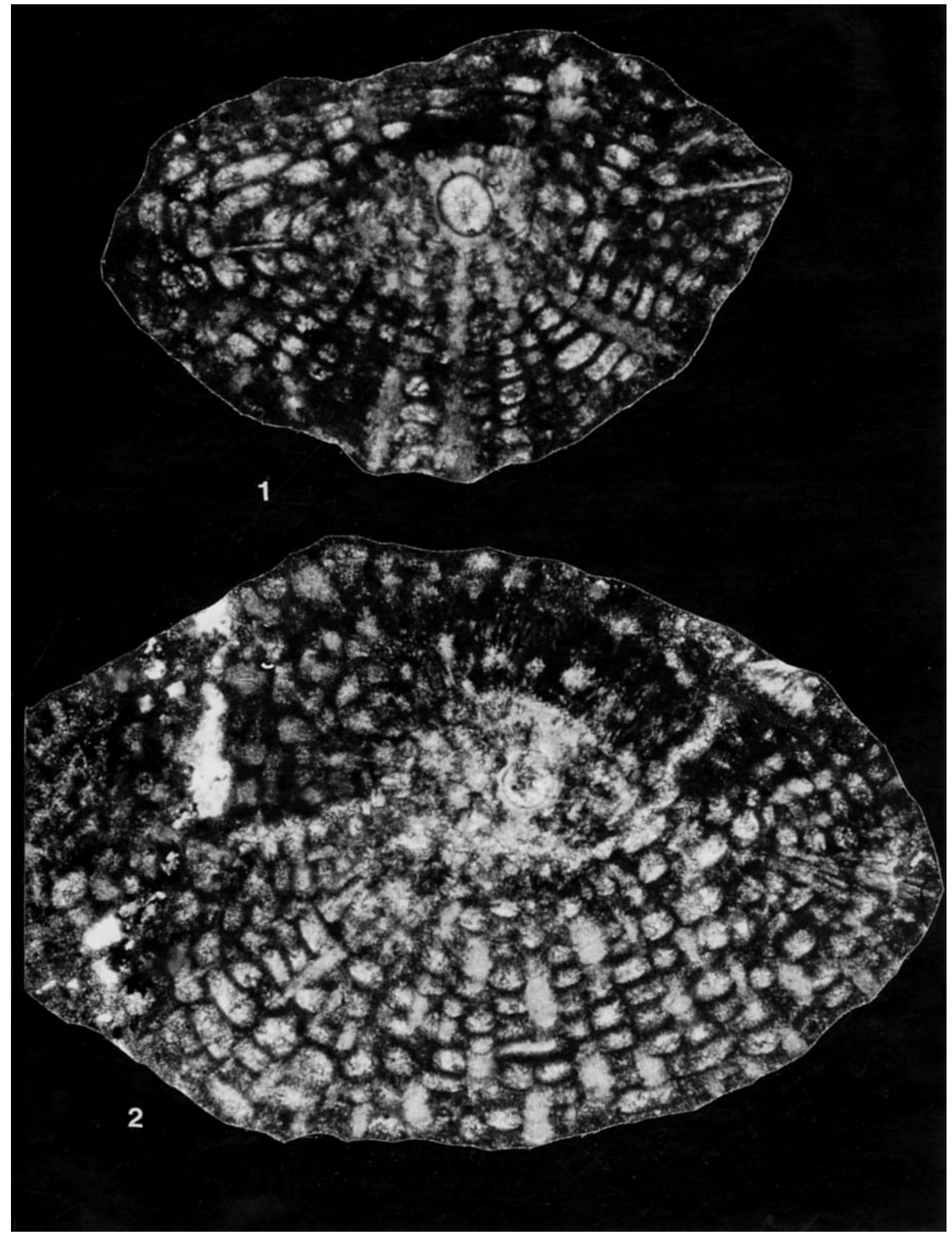

Plate 5 


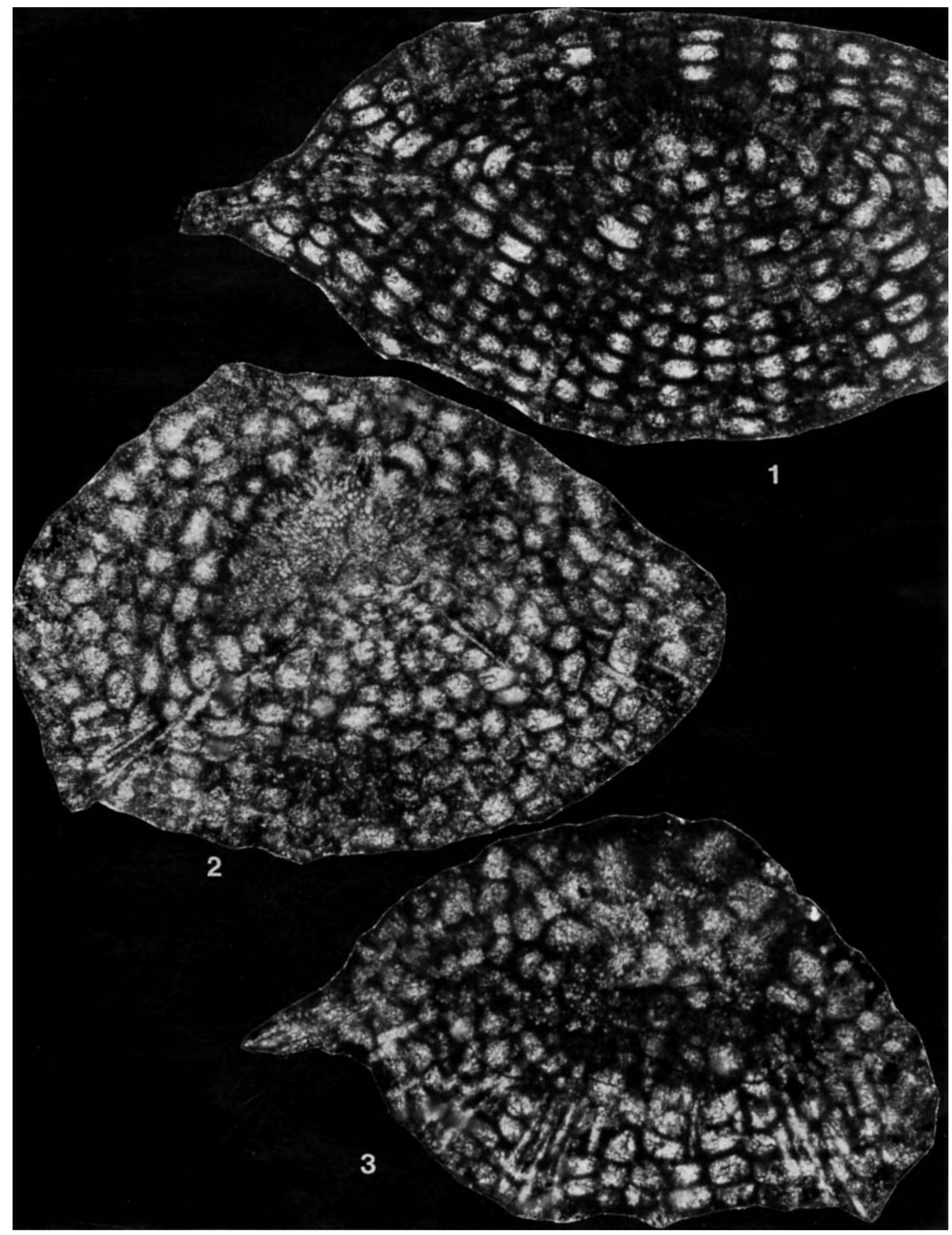

Plate 6 